\title{
Research on the Influencing Factors of RMB Internationalization in the Process of the Belt and Road Initiative
}

\author{
Tingting WU, Rui TANG \\ Finance school, Shanghai University of International Business and Economics \\ Shanghai, 201620
}

\begin{abstract}
The aim of this study is to explore what factors influence RMB internationalization in the process of the Belt and Road. It firstly makes a summary of the important influencing factors, then sets up a semi-logarithmic model to quantitatively analyze these factors, and finally puts forward suggestions for the steady development of RMB internationalization. Through literature review, it is found that since the Belt and Road initiative was put forward, RMB has been used more extensively in the surrounding countries and regions. Through quantitative research, it is found that with China's GDP as a share of world GDP, the scale of imports and exports of goods and services, and economic freedom are all positively related to the internationalization of RMB; the inflation rate and the volatility of real effective exchange rate are negatively related to it. This paper suggests that China should vigorously develop the national economy, expand the trade scale and maintain the stability of the RMB currency value. Meanwhile, it should also improve the market mechanism and increase economic freedom under the guidance of the central government. The marginal contribution of this study is to add to the econometric model an explanatory variable of economic freedom representing the impact of the Belt and Road initiative.
\end{abstract}

Keywords-RMB Internationalization; Influencing Factors; The Belt and Road; Stability of RMB Currency Value; Economic Freedom

\section{INTRODUCTION}

In recent years, $\mathrm{RMB}$ internationalization has developed rapidly and played an active role in various aspects. For example, RMB internationalization can promote the development of China's foreign trade. It can also make the domestic financial system more perfect and expand the scale of financial diplomacy. Additionally, it helps to promote the reform of the international monetary system. In 2013, general secretary Xi Jinping proposed to jointly build the Silk Road Economic Belt as well as a joint construction of the $21 \mathrm{st}$ Century Maritime Silk Road initiative. One Belt and One Road can provide a broad development platform for RMB internationalization, in return, RMB internationalization will pave the way for the construction and development of One Belt and One Road. It is of great significance and value to study the influencing factors of RMB internationalization in the development progress of One Belt and One Road.

This paper is organized as follows. The second part presents the literature summary. The third part makes theoretical analysis of currency internationalization. The fourth part presents the empirical analysis. The fifth part shows policy recommendations and the sixth part concludes.

\section{LITERATURE SUMMARY}

\section{A. Literature Review}

Before One Belt and One Road was put forward, many scholars began to discuss the internationalization of RMB. Eichengreen (2011)[1] pointed out that China's economy was large enough to create deep and liquid markets, in addition, there were a large volume of foreign trade and foreign investment in China, all of which created a platform for RMB trading among foreign countries. And then promote the internationalization of RMB. Subramanian and Kessler (2012) [2] assumed that trade was the only driving force, a more global exchange rate of RMB could emerge by the mid-2030s. Li Meizhou (2012)[3] analyzed the influencing factors of currency internationalization, such as the scale of economy, the scale of import and export market, the speed of currency appreciation as well as the stability of exchange rate. Besides, Li Meizhou (2012)[3] supposed that historical inertia was the main factor influencing currency internationalization. Zhong Yang and Ding Yibing (2013)[4] assumed that short-term interest rate and real GDP per capita were the most important factors. Moreover, they thought that short-term interest rate and currency holdings had a reverse effect on currency internationalization, therefore, the existence of externality could be proved.

After One Belt and One Road was proposed, some domestic scholars paid more attention to the internationalization of RMB. Ba Shusong (2016)[5] believed that the One Belt and One Road strategy was of great significance to the internationalization of RMB. During the One Belt and One Road process, the development of futures and derivatives markets where RMB was taken as the denominated currency would attract more overseas investors to hold $\mathrm{RMB}$, thus promoting the internationalization of RMB (Ba Shusong, 2016). Li Shuqing (2016)[6] found that under the One Belt and One Road background, the most important factors were the settlement of RMB in cross-border trade and the development of RMB offshore financial centers. Wang Xueyan (2017)[7] found that there were three factors, which included the actual per capita GDP of a country, the geographical relationship between the country and China as well as the central parity rate of the RMB against the U.S. dollar, being negatively related to the country's acceptance of 
the RMB. In contrary, the total bilateral trade volume with China, total foreign exchange reserves, and the RMB exchange rate appreciation index had positive relationships with the country's acceptance of the RMB (Wang Xueyan, 2017). Zhang Bin and Zhuang Huichao (2017)[8] believed that the factors included the size of the economy which had the most obvious influence, trade scale, economic freedom, as well as the stability of currency values.

Some scholars used an indirect estimation method to measure the degree of RMB internationalization. For example, the Research Group of the People's Bank of China Jinan Branch's Balance of Payments Division (2012)[9] studied the internationalization of the RMB by the RMB offshore stock. Based on the perspective of China's current balance of payments structure, they pointed out that the sustained and not-stable double surplus structure of payments and the slow export of RMB would hinder the process of internationalization of the RMB. Sha Wenbing (2014)[10] through empirical analysis found that there was a long-term and stable positive co-integration relationship between the offshore stock of RMB and the RMB exchange rate as well as China's trade status which had a greater degree of influence on the offshore stock of RMB.

\section{B. Literature Comments}

As can be seen from the above research, before the implementation of One Belt and One Road, most academics made analysis of the main factors influencing RMB internationalization from the aspects of economic scale, trade scale, currency stability and so on. After the introduction of One Belt and One Road policy, policy factors have been involved in the scope of empirical research. The degree of economic freedom is included by most scholars to study the degree of internationalization of RMB. For the measurement of RMB internationalization, there are several research results having proved the rationality and effectiveness of the RMB offshore stock size.

\section{THEORETICAL ANALYSIS OF CURRENCY INTERNATIONALIZATION}

\section{A. Meaning of Currency Internationalization}

$\mathrm{Xu}$ Xinhua (2006)[11] pointed out in his research literature that as early as 1971, Cohen explained the meaning of international currency from the perspective of monetary functions. Cohen thought that when the domestic function of money expanded to foreign countries, the currency had the function of international currency. A country would expand the country's currency to other countries for different purposes, which in turn would allow the currency to reach the level of the international currency. At the same time Xu Xinhua (2006) also pointed out that by 1998, Hartmann inherited and developed Cohen's definition of international currency and divided the functions of international currencies into three categories. They are payment functions, pricing functions and storage functions.

\section{B. Monetary Internationalization Theory}

\section{1) Monetary Substitution Theory}

In the analysis of the theory of currency substitution, Sun Dongsheng (2007)[12] said that the concept of Currency Substitution was put forward by Caruscetti in 1969. Currency substitution is an economic phenomenon in which good money expels bad money.

Taking the internationalization of RMB in the process of One Belt and One Road as an example. When countries along One Belt and One Road experience inflation or expect their exchange rates to depreciate, which erodes the confidence in their currencies, or when the opportunity cost of RMB assets is relatively low and the rate of return is relatively high, residents of the countries along the route will hold fewer local currencies and increase their holdings of the relatively high-valued RMB. Therefore, the RMB may gradually replace the currency of the countries along the route as a store of value or as a medium of trade. Such phenomena are often referred to as Currency Substitution. In the process of currency internationalization, the phenomenon of currency substitution takes place usually. Generally speaking, the higher the degree of internationalization, the higher the degree of currency substitution. The RMB would not completely replace the currency of the countries along the route, but the phenomenon of currency substitution exists, and it will promote the internationalization of RMB.

\section{2) Optimal Currency Area Theory}

In the Theoretical and Empirical Analysis of the Cross-border Circulation of RMB, Sun Dongsheng (2007) mentioned that Mondale explained the theory of optimal currency area in 1961. Mondale believed that in a currency region, demand shifts would impact economies, and the transfer of factors could eliminate this negative impact.

The construction of One Belt and One Road plays an important role in promoting the establishment of 'RMB Zone'. According to the theory of optimal currency area, the formation of optimal currency area also depends on the flow of factors of production, open economy, perfect financial markets, diversified commodities, complementary trade structure and policy support. In the process of One Belt and One Road, China and other countries along the route have joined hands in strengthening infrastructure construction, deepening cooperation in the fields of investment and trade, and promoting policy communication, etc. This has laid a solid foundation for the formation of RMB Zone and has also created favorable conditions for the internationalization of RMB. 


\section{Stage Analysis of RMB Internationalization}

From the theoretical analysis above, we can see that the process of $\mathrm{RMB}$ internationalization is closely related to these theories. In order to further explain the current situation of RMB internationalization and its influencing factors, this paper chooses two perspectives: the scale of RMB offshore stock and the amount of cross-border RMB settlement business.

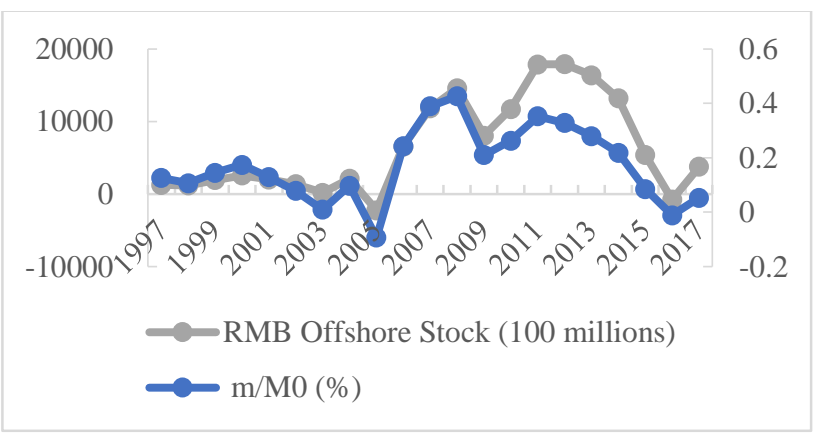

Fig. 1 Scale of RMB offshore stock from 1997 to 2017

Note: the data are derived from the size of the RMB offshore stock calculated in this paper using the indirect estimation method. The $\mathrm{m}$ represents RMB offshore stock, and the M0 represents the money in circulation.

From 1997 to 2017, the year 2005, 2008, 2009, 2012 and 2016 were taken as the turning points of the change of the offshore stock of RMB, which could be roughly divided into three stages: from 1997 to 2005, RMB offshore stock was relatively stable; from 2005 to 2008 , the large increase in the stock of RMB outside China was due to the fact that China began to reform the RMB exchange rate formation mechanism and implemented a floating exchange rate system in 2005. This reform was based on the supply and demand relationship in the market as well as the management of a basket of currencies. The reform not only reduced the obstacles to the floating of RMB but also raised the value of RMB, therefore, foreign investors were more willing to hold RMB. In 2008, the stock of RMB outside the country dropped down because of the global financial crisis. Since China's economy began to decline and trade volume decreased, China had decided to suspend the managed floating exchange rate system on RMB. In 2009, the stock of RMB outside the country increased again, mainly due to the expansion of the pilot projects of RMB cross-border trade settlement. The managed floating exchange rate system had been restarted. In 2012, the offshore stock of the RMB declined because of the intensified European debt crisis and the pressure from the strong dollar, as well as the downward pressure on the Chinese economy. The three economy situations caused a decline in RMB appreciation ability and made RMB devalue abnormally, thus the offshore stock of RMB declined until 2016 - another turning point ( $\mathrm{Yu}$ Daoxian 2015)[13].
1) From the Perspective of the Scale of RMB Stock Outside China

As the stock of RMB outside the country increases, the RMB may gradually replace the currencies of these countries along the route as a means of storing value or as a medium of trade (Sun Dongsheng 2007). According to the theory of currency substitution, such substitution process reflects the process of RMB internationalization to some extent.

The process of RMB internationalization measured by the size of the stock of RMB offshore is shown in Chart 1:

2) From the Perspective of Cross-border RMB Settlement Business Amount

The development of cross-border RMB settlement business, which began in 2009, represents an important step of RMB towards the international stage (Ma Bin 2015)[14]. According to the theory of optimal currency area, if the RMB is used as the main settlement tool in the peripheral area of One Belt and One Road, this will reduce the cost of currency settlement in trade, make the trade Optimal and form RMB Area. It can be seen that using the amount of cross-border trade RMB settlement business to analyze the process of RMB internationalization has a certain reference value.

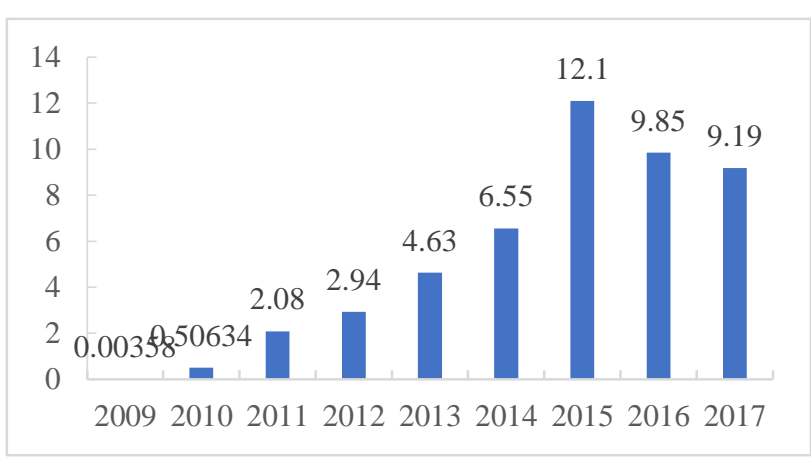

Fig. 2 RMB settlement for cross-border trade from 2009 to 2017 (trillion yuan)

Note: Data comes from China Monetary Policy Implementation Report.

<http://www.pbc.gov.cn/zhengcehuobisi/125207/125227/1259 57/126006/2835493/index.html>

According to the chart above, the scale of RMB in cross-border trade settlement had increased from 3.58 billion yuan in 2009 to 9.19 trillion yuan in 2017 since the start of the cross-border RMB settlement pilot. The main driving force of RMB cross-border settlement business growth came from the support of the government and the spontaneity of the market. In 2013, after the government proposed the One Belt and One Road policy, cross-border RMB settlement business increased significantly to 12.1 trillion yuan in 2015 . However, due to the fluctuation of RMB exchange rate and the downturn of China's foreign trade economy, the scale of RMB cross-border trade settlement showed a significant downward trend in 2016 , falling to 9.85 trillion yuan, declining by 19.5 percentage points from a year earlier. It was also the first decline since the launch of a cross-border RMB settlement pilot. 
From the analysis of the theory and the process of RMB internationalization, it can be seen that the internationalization of RMB is unstable due to the economic development of our country, the scale of cross-border trade, the inflation rate, the $\mathrm{RMB}$ exchange rate and the degree of government support.

\section{EMPIRICAL ANALYSIS}

From the previous literature review, we can see that the existing research results have laid a foundation for the empirical analysis of this paper, and these documents have a high reference value and a high reference significance. In addition, the third part of this paper is related to the theoretical analysis of the development stage of RMB internationalization, and then the empirical analysis will be carried out.

\section{A. Variable Selection and Data Preprocessing}

Different scholars have come up with different indicators to measure the degree of RMB internationalization. For example, the RMB Global Index (RGI), the RMB Internationalization Index (RII). This paper will adopt the method of establishing econometric model to analyze the influencing factors of RMB internationalization.

When it comes to the indicators of economic scale, trade scale, currency stability and policy financial environment, the details are as follows:

TABLE I The Statistics of Variable Selection

\begin{tabular}{llllll}
\hline Sources & Economic Scale & Trade Scale & Currency Stability & $\begin{array}{l}\text { Policy } \\
\text { Environment }\end{array}$ \\
\hline Wang Xueyan (2017) & RGDP & RIE & INF & EF & ER \\
Zhang Bing (2017) & $\sqrt{ }$ & $\sqrt{ }$ & & $\sqrt{ }$ & $\sqrt{ }$ \\
Li Shuqing (2016) & $\sqrt{ }$ & $\sqrt{ }$ & & & \\
Yu Daoxian (2015) & $\sqrt{ }$ & $\sqrt{ }$ & $\sqrt{ }$ & $\sqrt{ }$ & \\
Li Daokui (2008) & & $\sqrt{ }$ & $\sqrt{ }$ & $\sqrt{ }$ & \\
Cai Xiaohui (2011) & & $\sqrt{ }$ & & & \\
Zhong Yang (2013) & 3 & 6 & 2 & 5 & 1 \\
Frequency in the literatures & & & & \\
\hline
\end{tabular}

Notes: RGDP represents the proportion of China's GDP in the world's GDP; RIE signifies the proportion of China's trade volume in world trade volume; INF characterizes the inflation

The RGDP, RIE, INF, EF, and ER are added in the econometric model of the paper as independent variables. Among them, ER, which represents the economic freedom index, is selected as the policy financial index, and uses the economic freedom index to measure the degree of economic openness, the degree of government intervention as well as the level of financial market development in the progress of the One Road and One Belt (Zhang \& Zhuang, 2017).

Based on the previous analysis, the offshore stock of RMB is taken as the measure of the internationalization of RMB by many scholars. The methods of estimating the offshore stock

$$
\begin{array}{cc}
\ln \left(M_{0_{t}} / P_{t}\right)=0.4245 \ln \left(G D P_{t} / P_{t}\right)+1.7307 X_{t}-4.9637 \text { Tax }_{t}+0.0216 R_{t}+0.1982 \\
F-\text { sstatistic }=495.8642 & \operatorname{Prob}(F-\text { statistic })=0.000000 \\
R^{2}=0.992991 & \text { Adjusted } R^{2}=0.990989
\end{array}
$$

The second step is that the true value of $\ln \left(M_{0} / P_{t}\right)$ represents the amount of the actual money demand after logarithm, and the predicted value of $\ln \left(M_{0} / P_{t}\right)$ represents the value of the domestic monetary demand after logarithm calculated by the semi-logarithmic model. According to the principle of deducting local demand method and the theory that says supply and demand are equal, the progress that the real value minus the predicted value and then undo the logarithm is used for the measured value of RMB offshore stock.

\section{B. Construction of the Econometric Model}

Based on the analysis of the selected dependent variables, this paper measures the degree of RMB internationalization by using the estimated value of the stock scale of RMB offshore, denoted by the letter $\mathrm{m}$. The economic scale, the scale of trade, the degree of currency stability and the degree of economic freedom are set up as the explanatory variables. According to the views of most scholars, RMB cross-border flows began in 1997, and some scholars have started to use annual data to conduct empirical analysis of RMB internationalization as early as five years ago. The empirical results with high reliability are obtained and has been proved. Hence the annual 
data from 1997 to 2017 will be selected as the sample data of each variable in the model in this paper. The specific

$$
\operatorname{lnm}_{\mathrm{t}}=\beta_{0}+\beta_{1} \operatorname{rgdp}_{\mathrm{t}}+\beta_{2} \text { rie }_{\mathrm{t}}+\beta_{3} \mathrm{inf}_{\mathrm{t}}+\beta_{4} \mathrm{er}_{\mathrm{t}}+\beta_{5} \mathrm{ef}_{\mathrm{t}}+\varepsilon_{\mathrm{t}}
$$

The model variable is explained as follows: $m_{t}$ denotes the size of RMB offshore stock measured by indirect estimation method. The $\operatorname{rgdp}_{\mathrm{t}}$ denotes the GDP of our country as a percentage of the world GDP. The annual data for China's GDP and the world GDP are from the World Bank. The rie $e_{t}$ means the total import and export of goods and services of our country as a percentage of the world's total imports and exports of goods and services, and they are derived from the World Development Index. Accordingly, the $\operatorname{rgdp}_{\mathrm{t}}$ equals the sum of our imports and exports divided by the sum of the world's imports and exports. The inf $\mathrm{t}_{\mathrm{t}}$ represents the inflation as measured by China's GDP deflator index (annual inflation rate), data from the World Bank. The $\mathrm{er}_{\mathrm{t}}$ denotes the volatility of the real effective exchange rate index, which is based on China's 2010 as the reference year $(2010=$ 100). The volatility is derived from the base period of the previous year. The original data is from the World Bank. The $\mathrm{ef}_{t}$ indicates our country's economic freedom index. The data is from the America Heritage Foundation.

Because the stationarity of time series variables is uncertain, a unit root test of each variable is required before co-integration analysis. In the model, variables inf and er reject the original hypothesis at the significant level of $10 \%$, that is, there is no unit root, but the variables $\operatorname{lnm}$, rgdp, rie and ef do not reject the original assumption at the significant level of $10 \%$, that is, the existence of unit root. However, after the second order difference treatment, all variables do not accept the original hypothesis at the significant level of $1 \%$, and the $\mathrm{ADF}$ detection values of each variable are smaller than all critical values, indicating that all the sequences are second-order difference stationary. Therefore, all time series in satisfy the premise of co-integration analysis.

Then we can use the Granger test to study the causal relationship between the explanatory variables and the interpreted variables in the model. There is a one-way Granger causality relationship between the explanatory variables rgdp, rie and the explained variable $\mathrm{lnm}$, that is, the change of rgdp and rie will cause the change of the offshore stock of RMB, while the change of the offshore stock of RMB will not lead rgdp or rie to change. There is no Granger causality between the interpretive variable inf and the explained variable $\mathrm{lnm}$. However, there is a reverse Granger causality between the explanatory variable er and the explained variable $\mathrm{lnm}$, that is, the change of the stock of RMB outside China will cause the change of er.

Based on ADF test and Granger causality test, this paper uses E-G co-integration test method to trial whether there is co-integration relationship between variables in the model. The test method is divided into two steps: the first step is the least square regression of the model to obtain the regression equation and the corresponding residual terms; the second step is to check whether the residual sequence has unit root to see if it is stable.

From the results of the least squares regression, we can see that all the variables except the rgdp and the ef are significant in $10 \%$ confidence level. After the least significant variable, the rgdp is removed by stepwise regression, and the results of least squares regression are as follows: the model are second-order single-integer time series, which

$$
\begin{array}{rrrr}
\operatorname{lnm}=22.9332 \text { rie } & -1.8412 \mathrm{inf} & -1.9942 \mathrm{er} & +0.0771 \mathrm{ef} \\
(20.6094) & (-1.8188) & (-3.1212) & (54.7210)
\end{array}
$$

$$
\text { Adjusted } R^{2}=0.963293
$$

It can be seen that inf is significant at $10 \%$ confidence level, and the other three variables are significant at $1 \%$ confidence level. Especially the EF variable is not significant in the previous regression results, but after excluding rgdp, impact of economic freedom on the internationalization of $\mathrm{RMB}$ is significant. Based on the previous literature review and theoretical analysis, it can be concluded that rgdp, which the EF variable is very significant, which indicates that the represents economic scale, is one of the core factors affecting $\mathrm{RMB}$ internationalization. This paper retains the core explanatory variable rgdp. Insignificance in the results of the least-squares regression of the model cannot be denied the significance in fact. As result, this paper will keep the key indicator rgdp in the empirical model. Based on the regression results, the model is established as follows:

$$
\begin{aligned}
& \operatorname{lnm}=3.9657 \quad+8.0667 \mathrm{rgdp} \quad+21.7000 \mathrm{rie} \quad-2.5631 \mathrm{inf} \quad-2.2090 \mathrm{er} \quad+0.0042 \mathrm{ef} \\
& \text { (2.9122) } \\
& \text { (-0.0479) } \\
& \text { (4.5500) } \\
& (-2.0474) \quad(-4.019646) \\
& (0.1667) \\
& \text { (Formula 2) } \\
& F-\text { sstatistic }=100.7219 \\
& \operatorname{Prob}(F-\text { statistic })=0.0000 \\
& R^{2}=0.972953 \\
& \text { Adjusted } R^{2}=0.963293
\end{aligned}
$$


The coefficient $\mathrm{R}^{2}$ is 0.972953 , and the revised coefficient is 0.963293 , which indicate that the explanatory variable has a higher degree of explanation to the explained variable. The F-test value of the equation is 100.7219 , and the whole model

The unit root test of model residual $\varepsilon \mathrm{t}$ is carried out. From the result, we can get the original hypothesis that $\varepsilon_{\mathrm{t}}$ rejects the existence of unit root at the significant level of $5 \%$, in other words, the residual $\varepsilon_{\mathrm{t}}$ does not have unit root and is a stationary sequence. This indicates that there is a long-term co-integration relationship between the explanatory variables and the explained variable.

\section{Quantitative Regression Analysis}

Based on the results of the econometric regression, the analysis of the five explanatory variables is as follows:

For every 1 percentage point increase in rgdp, lnm will increase by 8.0667 percentage points. That means that every $1 \%$ increase in the proportion of China's GDP to world GDP will increase $8.067 \%$ of the RMB's offshore stock. The absolute value of the coefficient of this explanatory variable is relatively large, which indicates that the economic scale affects the degree of internationalization of RMB to a large extent, compared with other variables.

For every 1 percentage point increase in rie, $\operatorname{lnm}$ will increase by 21.7000 percentage points. That means if the amount of import and export in China's trade and services account for $1 \%$ of the world's trade and service import and export volume, it will increase the overseas stock of RMB by $21.700 \%$. The absolute value of the coefficient of this explanatory variable is the largest, indicating that among all the variables of the model, the scale of trade has the greatest impact on the internationalization of RMB.

For every 1 percentage point increase in inf, lnm will decrease 2.5631 percentage points, that is, every $1 \%$ increase in China's inflation rate will reduce the overseas stock of RMB by $2.5631 \%$.

For each unit increase in er, the $\operatorname{lnm}$ will be reduced by 2.2090 percentage points. That is to say, if the actual effective exchange rate index of China floats $1 \%$ compared to the previous year's, the overseas stock of RMB will be reduced by $2.2090 \%$.

For each unit expanded by ef, $\operatorname{lnm}$ will increase by 0.00419 percentage points. That is to say, for each additional 1 point of China's economic freedom index, the overseas stock of RMB will increase by $0.00419 \%$.

\section{POLICY RECOMMENDATIONS}

The empirical results show that firstly the economic scale and trade scale of our country are positively correlated with RMB internationalization and have a great promoting effect. And secondly, the volatility of inflation rate and real effective exchange rate are negatively correlated with RMB internationalization. That is, RMB currency stability can promote the internationalization of RMB. Thirdly, the economic freedom is positively correlated with RMB is significant at the level of $1 \%$. At the confidence level of $1 \%$, the variable rie is the most significant variable coefficient, and the coefficients of the other variables conform to the economic meaning. The model fits well as a whole.

Finally, a short-term error correction model is carried out. The result shows that the coefficient of the modified term ECM (-1) is -0.8993 and is significant in the confidence interval of $10 \%$. Subsequently, when the short-term fluctuation deviates from the long-term equilibrium, the non-equilibrium state will be adjusted with the strength of -0.8993 to reach the equilibrium state. $\mathrm{R}^{2}$ is 0.6607 , which indicates that the fitting effect is reasonable.

internationalization, but the role of promotion is minimal. Therefore, this paper will put forward some policy suggestions to the internationalization of $\mathrm{RMB}$ in the process of One Belt and One Road.

\section{A. Vigorously Develop the National Economy}

Through empirical analysis, this paper draws the conclusion that the economic scale can promote the internationalization of $\mathrm{RMB}$, which is consistent with the conclusions of many scholars. China's growing economic strength is an important driving force for the internationalization of RMB. In the process of One Belt and One Road, what should not be ignored is the development of the national economy, maintaining the medium and high-speed growth of the economy, striving to realize the economic transformation and upgrading, and giving play to the role of the world's second largest economy in promoting the internationalization of the RMB.

\section{B. Expand the Scale of Trade and Coordinate the Development of Imports and Exports}

At the beginning of reform and opening up, China has always emphasized expanding the scale of exports and maintaining a trade surplus. In the development of One Belt and One Road, China's import volume has been increasing and its import scale has been continuously expanding. To a certain extent, this foreign trade phenomenon indicates that China's trade structure may change from a trade surplus to a trade deficit. On the premise of this possibility, combined with the empirical analysis results of this paper, it is suggested that China should expand the import scale from the neighboring countries along with the One Belt and One Road and optimize the import structure while coordinating the development of import and export trade. "From a systemic point of view, expanding the size of imports and tying up the economies of more countries can weaken the hegemony of the US dollar, expand imports will also expand the use of the RMB for foreign purposes, and also play a supportive role in the internationalization of the RMB." This is a little bit different from the policy suggestions of more literature on RMB internationalization, but it also has some practical significance. 


\section{Keep the Value of RMB Stable and Appropriately Reduce the Value of RMB}

The empirical results show that there is a negative correlation between the inflation rate and the real effective exchange rate index and the offshore stock of RMB. The inflation rate should not be too high, and a lower inflation rate not only helps to maintain price stability, but also promotes the internationalization of the RMB.

\section{Increase in the Index of Economic Freedom}

Through the experimental results, there is a positive correlation between the economic degree of freedom and the offshore stock of RMB, but the effect is too small. At present, the mechanism of domestic financial market in China is not perfect enough. The excessive improvement of the degree of market openness and freedom may make our currency suffer the impact of a large number of foreign capital flowing into our country, which will have a negative impact on the stability of our country's economy. Thus, it is not conducive to the internationalization of the RMB. In addition, the One Belt and One Road strategy is an economic development policy put forward by China. It means that RMB internationalization needs the guidance of the government, which has the ability to enhance the international status of RMB and promote the internationalization of RMB.

\section{CONCLUSION AND PROSPECT OF RESEARCH}

\section{A. Conclusion}

This paper makes research on the factors affecting the internationalization of the RMB in the process of One Belt and One Road. The qualitative study shows that since the One Belt and One Road strategy was put forward, China's trade activities with the countries along the route have become more frequent. Besides, the investment and construction have become more active and the use of RMB across borders has become more widespread. The influencing factors include the scale of economy, the scale of trade, the stability of RMB value and the degree of economic freedom. The quantitative study shows that the proportion of GDP in world GDP, the scale of import and export of goods and services, and the degree of economic freedom are positively related to the internationalization of RMB, while the inflation rate and the real effective exchange rate index are negatively related to the internationalization of RMB.

\section{B. Prospect of Research}

\section{1) Research Deficiencies}

Due to the short history of RMB internationalization, its influence factors are numerous and complex, and the relevant data are not easy to obtain, the research of this paper has some shortcomings. Further improvement and exploration will be carried out in the future research.

\section{2) Future Research Direction}

This paper refers to the overseas stock scale of RMB which is widely recognized by many scholars to measure the degree of RMB internationalization. However, there are many other indicators which can also measure the level of RMB internationalization. Thus, we will explore which indicator is more appropriate for measurement in the future. In addition, this paper discusses the economic scale, the scale of trade, the degree of stability of RMB currency value and the degree of economic freedom, while ignoring the development of financial markets, Internet big data and other factors that have an important impact on economic development. Therefore, we will continue to select more explanatory variables to make the model more accurate, thus to make policy recommendations more reliable. In a word, it is hoped that the research of related topics could make a breakthrough with the development of One Belt and One Road.

\section{ACKNOWLEDGMENT}

This paper is financially supported by the National Social Science Foundation Project (16CGJ006).

\section{REFERENCES}

[1] Barry Eichengreen. The renminbi as an international currency[J]. Journal of Policy Modeling,2011,33(5).

[2] Arvind Subramanian,Martin Kessler. The Renminbi Bloc is Here: Asia Down, Rest of the World to Go? <sup $>1)</ \sup >[\mathrm{J}]$. Journal of Globalization and Development,2013,4(1).

[3] Meizhou, L 2012, 'Research on Influencing Factors of Currency Internationalization-Based on Multinational Panel Data Econometric Analysis', Shanghai Finance, no. 12, pp. 28-30+120 (In Chinese).

[4] Yang, Z \& Yibing, D 2013, 'The Influencing Factors and Externalities of Currency Internationalization', Shanghai Finance, no. 12, pp.54-57 (In Chinese).

[5] Shusong, B 2016, "The "Belt and Road" strategy is of great significance to the internationalization of the renminbi', Futures Daily, 22 March, P. 008 (In Chinese).

[6] Shuqing, L 2016, 'An Empirical Analysis of RMB Internationalization under the "One Belt and One Road" Policy', in Proceedings of 2016 2nd International Conference on Humanity and Social Science, Jeep, Thailand, August 28, 2016, Thailand Jeep, pp. 06 (In Chinese).

[7] Xueyan, W 2017, 'An Empirical Analysis of the Influence Factors of RMB Internationalization under the Background of "One Belt, One Road"-A Case Study of 13 Neighboring Countries in China', Journal of Chongqing Jiaotong University (Social Sciences), vol. 17, no. 05, pp. 70-74+81 (In Chinese).

[8] Bin, Z \& Huichao. Z 2017, 'An Empirical Analysis of the Influencing Factors of RMB Internationalization in the Belt and Road Initiative Process', Jilin Finance Research, no.06, pp.40-46 (In Chinese).

[9] The Research Group of the Balance of Payments Branch of the People's Bank of China Jinan Branch, Defu, B \& Lianying, L 2012, 'The influence of China's current balance of payments structure on the internationalization of RMB', Research on Financial Development, no. 10, pp. 60-63.

[10] Wenbing, S 2014, 'Changes in Exchange Rate, Trade Status and Foreign Exchange of RMB: Empirical Analysis Based on Monthly Data from 1994 to 2012', Journal of Zhongnan University of Economics and Law, no. 01, pp. 3-9+158 (In Chinese).

[11] Xinhua, X 2006, 'Research on RMB internationalization: theory and demonstration', PhD. thesis, Fudan University (In Chinese).

[12] Dongsheng, S 2007, 'Theory and Empirical Analysis of RMB Cross-border Circulation', PhD. thesis, Southwestern University of Finance and Economics (In Chinese).

[13] Daoxian, Y \& Yun, W 2015, 'An Analysis of the factors influencing the process of RMB internationalization: based on the Perspective of balance of payments', World Economic Studies, no. 3, pp.3-14+127 (In Chinese).

[14] Bin, M 2015, 'Research on the Influencing Factors of RMB Internationalization', PhD. thesis, Dongbei University of Finance and Economics (In Chinese). 